\title{
O desafio que a educação permanente tem em si: a pedagogia da implicação
}

Emerson Elias Merhy ${ }^{1}$

Neste texto Ricardo faz um desafio: a produção do cuidado em saúde e sua micropolítica são constituídas de práticas pedagógicas, e não só de ações tecnológicas típicas da construção de atos de saúde, no senso estrito; portanto, toda aposta que visa interferir no campo de produção da saúde tem de reconhecer isso como uma necessidade para a ação. Este autor, dando conseqüência a esta noção, propõe uma problematização sobre a educação em saúde, advogando com muitos outros a idéia da educação permanente e passando a reconhecer que: "torna-se crucial o desenvolvimento de recursos tecnológicos de operação do trabalho perfilados pela noção de aprender a aprender, de trabalhar em equipe, de construir cotidianos eles mesmos como objeto de aprendizagem individual, coletiva e institucional."

Creio que este desafio nos permite a construção de uma grande pauta de discussões e reflexões e, até mesmo, de novas produções teóricas. Entretanto, aqui e agora, estou estimulado por duas idéias em particular, para olhar o que considero nuclear no desafio proposto.

Uma delas, refere-se a um fenômeno bem comum entre nós. Não é possível sustentarmos mais as quase exclusivas visões gerenciais que se posicionam sistematicamente pela noção de que a baixa eficácia das ações de saúde é devida à falta de competência dos trabalhadores e que pode ser corrigida a medida que suprimos, por cursos compensatórios, aquilo que Ihes falta. Diante desta visão do problema, estes gestores passam a propor cursinhos à exaustão, que consomem recursos imensos e que não vêm gerando efeitos positivos e mudancistas nas práticas destes profissionais.

Óbvio que, aqui, não estou jogando a criança com a água do banho; há treinamentos que são necessários para a aquisição de certas técnicas de trabalho, mas isso é pontual e pode ser suprido sem muita dificuldade. $O$ que aponto é a necessidade de olharmos de outros modos explicativos para esta relação em dobra: educação em saúde e trabalho em saúde, na qual é impossível haver separação de termos. Um produz o outro. Com efeitos fundamentais tanto para a construção da competência do trabalhador, quanto para a expressão de seu lugar enquanto sujeito ético-político produtor de cuidado, que impacta o modo de viver de um outro, material e subjetivamente constituído (o usuário, individual e/ou coletivo). Aliás, estas questões já vêm sendo objeto de preocupações da própria equipe de trabalho da qual o Ricardo faz parte.

${ }^{1}$ Professor, Universidade de Campinas, Unicamp. <emerson.merhy@gmail.com>

Rua Ana Fratta de Paula, 176, casa 30

Sousas - Campinas, SP

13.014-028

Interface - Comunic, Saúde, Educ, v.9, n.16, p.161-77, set.2004/fev.2005 
O projeto do Ministério da Saúde, do Governo Lula, sobre os Pólos de Educação Permanente vem constituindo uma forma de construir um terreno para a problematização necessária da mudança do conjunto das práticas dos gestores da saúde quanto a suas intervenções no campo da educação em saúde, enquanto pauta nacional. Como instância do SUS, esses Pólos não necessariamente respondem de modo uniforme a esta pauta, pois a instalação de múltiplos atores loco-regionais lhe dão singularidades que não podem ser desprezadas. Mas o terreno e o sentido da política estão aí instalados, cabendo aos atores concretos resolvê-los nos seus modos de produzir o SUS, no Brasil. Não há solução para estes processos à parte daquela que é encontrada para a constituição do SUS como institucionalidade. A multiplicidade desta se expressa também nos Pólos.

Esta dimensão está articulada ao desafio que Ricardo provoca e a tocarei na reflexão da minha segunda grande questão, que tem a ver, no meu ponto de vista, com o tipo de prática de educação que deve ser induzida, que deve ser construída, nos marcos deste debate da educação permanente. Ou seja, tem a ver com certo posicionamento necessário em relação ao modo de encarar a construção das ações no campo da saúde e da educação, implicadas com a visão em dobra destes dois territórios de práticas sociais, já citada anteriormente.

Ricardo aponta isso em vários momentos de seu texto, reafirmando a importância do lugar do trabalhador como protagonista efetivo deste processo: "à área da formação, então, não mais um lugar secundário ou de retaguarda, mas um lugar central, finalístico às políticas de saúde. A introdução desta abordagem retiraria os trabalhadores da condição de "recursos" para o estatuto de atores sociais das reformas, do trabalho, das lutas pelo direito à saúde e do ordenamento de práticas acolhedoras e resolutivas de gestão e de atenção à saúde."

Quando fala da pedagogia do processo que possa estar articulado a este novo agir, aponta como dispositivos analisadores, que podem instituir novas lógicas no agir do trabalhador, o "quadrilátero da formação", apostando que ele pode cumprir este núcleo do desafio, procurando mostrar a possibilidade auto-analítica desses componentes.

De modo correto, mostra que todo processo que esteja comprometido com estas questões da educação permanente tem de ter a força de gerar no trabalhador, no seu cotidiano de produção do cuidado em saúde, transformações da sua prática, o que implicaria força de produzir capacidade de problematizar a si mesmo no agir, pela geração de problematizações "- não em abstrato, mas no concreto do trabalho de cada equipe - e de construir novos pactos de convivência e práticas, que aproximem os serviços de saúde dos conceitos da atenção integral, humanizada e de qualidade, da eqüidade e dos demais marcos dos processos de reforma do sistema brasileiro de saúde, pelo menos no nosso caso."

E aí está o cerne de um grande novo desafio: produzir auto-interrogação de si mesmo no agir produtor do cuidado; colocar-se ético-politicamente em discussão, no plano individual e coletivo, do trabalho. E isto não é nada óbvio ou transparente.

Não me parece que para gerar "auto-análise e autogestão dos coletivos" o "trabalho com eixo na integralidade" tenha força em si, ou mesmo, que "as consultorias, os apoios, as assessorias quando implementadas" tenham capacidade de gerar isso com os analisadores (do quadrilátero) da Educação Permanente em Saúde, se não conseguirem atingir a alma do operar ético-político do trabalhador e dos coletivos na construção do cuidado, que é o modo como estes dispõem do seu trabalho vivo em ato, enquanto força produtiva do agir em saúde. 


\section{DEBATES}

Parece que estamos diante do desafio de pensar uma nova pedagogia - que usufrua de todas as que têm implicado com a construção de sujeitos auto-determinados e comprometidos sócio-historicamente com a construção da vida e sua defesa, individual e coletiva - que se veja como amarrada a intervenção que coloca no centro do processo pedagógico a implicação ético-político do trabalhador no seu agir em ato, produzindo o cuidado em saúde, no plano individual e coletivo, em si e em equipe.

Colocar isto em análise, cobra dos dispositivos analisadores (os do quadrilátero) uma certa amarração com os componentes nucleares da micropolítica da produção do cuidado em saúde, individual e coletivo. Isto significa que o analisador tem de ter a potência de expor o trabalho vivo em ato para a própria auto-análise e pedagogicamente abrir espaços relacionais para poder se falar e se implicar com isso.

Esta pedagogia da implicação, parece-me inseparável do desafio que Ricardo aponta para a Educação Permanente. Construí-la no cotidiano dos serviços de saúde e como eixo ordenador de ações nos Pólos deve ser uma perseguição implacável para quem quer efetivamente mudar o modo de se fabricar saúde, entre nós.

Por isso, aponto que para a educação permanente de fato tornar-se um bom desafio, fazse necessário trabalhar este outro desafio em si, ainda muito em aberto, e que pede para ser enfrentado de modo mais ampliado do que já se tem de elaboração.

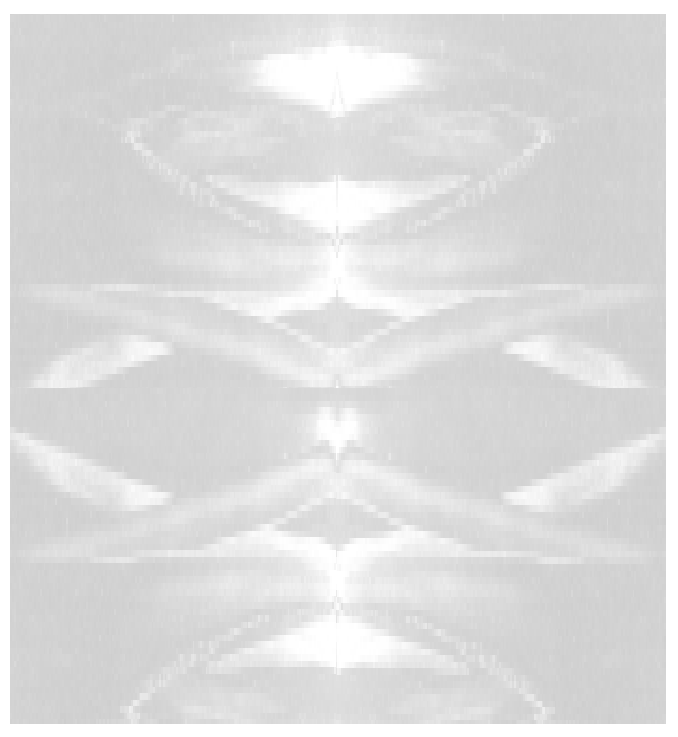

